\title{
Myxomycetes in Alagoas state (Brazil) and notes on its distribution
}

\author{
Andrea Carla Caldas Bezerra ${ }^{1 *}$ \\ Vitor Xavier de Lima ${ }^{1}$ \\ Juciara Carneiro Gouveia Tenório ${ }^{2}$ \\ Laise de Holanda Cavalcanti ${ }^{1}$ \\ ${ }^{1}$ Laboratório de Myxomycetes, Departamento de Botânica \\ Centro de Ciências Biológicas, Universidade Federal de Pernambuco \\ Avenida Prof. Moraes Rego s/n, Cidade Universitária, CEP 50670-420 Recife - PE, Brasil \\ ${ }^{2}$ Faculdade de Ciências Humanas e Aplicadas do Belo Jardim \\ Departamento de Ciências Biológicas \\ Sitio Inhumas Rod. PE 166, km 05, CEP 55.150-000, Belo Jardim - PE, Brasil \\ * Autor para correspondência \\ labmix@gmail.com
}

\section{Resumo}

Myxomycetes do estado de Alagoas (Brasil) e notas sobre sua distribuição. O estado de Alagoas, localizado na Região Nordeste do Brasil, abrange uma área de $27.767 \mathrm{~km}^{2}$ onde diferentes ecossistemas, incluindo manguezal e Floresta Atlântica na costa e caatinga no interior, são encontrados. A literatura relata a ocorrência de 43 espécies de Myxomycetes no estado, as quais foram registradas em ambientes florestais úmidos ou em bagaço de cana de açúcar armazenado em indústria. Este estudo é o primeiro a registrar espécies de Didymiaceae e os gêneros Badhamia, Comatricha, Perichaena, Reticularia e Stemonaria para Alagoas. É apresentada uma chave para espécies. Licea succulenticola, Reticularia jurana e Stemonaria longa são novas referências para o bioma Caatinga. Licea succulenticola é registrada pela primeira vez no Brasil.

Palavras-chave: Caatinga; Corologia; Floresta Atlântica; Mixobiota

\section{Abstract}

The state of Alagoas is located in the northeastern region of Brazil, and covers an area of 27,767 $\mathrm{km}^{2}$. Several different ecosystem types exist in this area, including mangroves forests and Atlantic rainforest on the coast, and Caatinga inland. The literature reports the occurrence of 43 species of Myxomycetes in Alagoas, all of which are recorded in humid forest environments, or in stored sugarcane bagasse. This study is the first one to record members of family Didymiaceae, and the genera Badhamia, Comatricha, Perichaena, Reticularia and Stemonaria in Alagoas. A species key is presented. Licea succulenticola, Reticularia jurana and Stemonaria longa are new references for the Caatinga biome. Licea succulenticola is also reported for the first time in Brazil.

Key words: Atlantic Forest; Caatinga; Corology; Myxobiota 


\section{Introduction}

Studies of Myxomycetes are scarce in the state of Alagoas (northeastern Brazil). The first records of occurrence were all from stored sugar cane bagasse (CAVALCANTI et al., 1985; SANTOS et al., 1986; SANTOS; CAVALCANTI, 1988). Sporadic sampling has been carried out on small farms within the state, which resulted in the first report of Echinostelium arboreum Keller \& Brooks in Brazil (CAVALCANTI, 2002). After exploring four fragments of the 'Serra Grande' sugarcane mill (in the municipalities of Ibateguara and São José da Lage), Cavalcanti et al. (2006) were the first to describe the occurrence of another 38 Myxomycetes species in the Atlantic rainforest, increasing the number of known species in the state to 43 . In the present study, notes on the distribution of some of those species are presented, as well as new species records for the Caatinga biome and for Brazil.

\section{Material and Methods}

The state of Alagoas covers $0.5 \%$ of the total area of Brazil, and $2.87 \%$ of the northeastern region - with a total area of $27,767 \mathrm{~km}^{2}$. It borders Pernambuco state in the North $\left(8^{\circ} 48^{\prime} 12^{\prime \prime} \mathrm{S}\right)$, Sergipe in the South $\left(10^{\circ} 29^{\prime} 12^{\prime \prime}\right.$ ) $)$, Bahia in the Southwest (35'09'36”S), and the Atlantic Ocean in the East (38 $13^{\circ}$ '54'S) (PEIXOTO; LIMA JUNIOR, 2006). The climate is tropical humid on the coast and semi-arid within the continent; the latter has annual precipitation between 500 and $600 \mathrm{~mm}$, with scarce and poorly distributed rainfall and an intense period of drought. The average annual temperature is between 25 and $27^{\circ} \mathrm{C}$ in the warmer period, and $21^{\circ} \mathrm{C}$ in the cooler months (PLGBB, 1988). The vegetation types along the coast vary from plain mangroves to a thin strip of Atlantic Forest. Caatinga is the predominant vegetation inland, as well as across the state (PEIXOTO; LIMA JUNIOR, 2006), and has been highly modified due to agricultural activities and the extraction of coal and firewood (SANTOS; TABARELLI, 2002).

We collected samples on a private farm located in the São José da Tapera municipality $\left(9^{\circ} 32^{\prime} 42^{\prime}\right.$ 'S, $37^{\circ} 23^{\prime} 00^{\prime}$ 'W), which is predominantly in the 'Pão de Açúcar' localization. Altitudes here vary between
220 and $255 \mathrm{~m}$, representing typical landscape for semi-arid regions. Local vegetation consists of hyperxerophilous shrub-arboreal caatinga vegetation. The climate is semi-arid tropical, with the rainy season occurring from November to April and with an average annual precipitation of $431.8 \mathrm{~mm}$ (CPRM, 2005). We investigated potential microhabitats for Myxomycete sporulation, such as rotting wood and species of Cactaceae, Agavaceae and Bromeliaceae (Figure 1). A list of Myxomycetes species occurring in the state of Alagoas was compiled using the literature (CAVALCANTI et al., 1985; 2006; SANTOS et al., 1986; SANTOS; CAVALCANTI, 1988; CAVALCANTI, 2002; 2013a), herbarium material (UFP) and specimens collected in this study.

Dead litter of unidentified Bromeliaceae $(35 \mathrm{mc})$, dead cladodes of three species of Cactaceae in the Opuntia (15 mc), Cereus (25 mc) and Pilosocereus (25 $\mathrm{mc}$ ) genera were collected, stored in sterile plastic bags, and placed in moist culture chambers (100). These were moistened, and after 24 hours water $\mathrm{pH}$ was measured. Cultures were maintained for minimally three months (STEPHENSON et al., 1999).

Representative specimens were deposited at Herbaria URM and UFP (respectively at the Mycology and Botany Departments of the University Federal of Pernambuco, Brazil). Identification was based on Martin and Alexopoulos (1969), Farr (1976), Lado and Pando (1997), Mosquera et al. (2003), Martin et al. (1983); Lado (2013) was used for nomenclature and author abbreviations.

\section{Results and Discussion}

Arcyria cinerea (Bull.) Pers., Syn. Meth. Fung. 184 (1801)

Selected specimens. BRAZIL, Alagoas, municipality of São José da Tapera, Pilosocereus sp., cultivated 19 June, sporulating 08 July, leg. A.C.C. Bezerra (UFP 54,896). Ibdem, sporulating 17 July, leg. A.C.C. Bezerra (UFP 54,895). Ibdem, sporulating 04 Aug, leg. A.C.C. Bezerra (URM 80,042).

Recorded in Brazil in the northern (Acre, Amazonas, Pará, Roraima), northeastern (Alagoas, Bahia, Ceará, 
FIGURE 1: A - Study area in the municipality of São José da Tapera (A - indicated with a blue square) and potential microhabitats for myxomycetes sporulation (B-E); B - Pilosocereus pachycladus Ritter.; C - Opuntia inamoena K. Schumann; D - Bromelia sp. E-Cereus jamacaru DC.

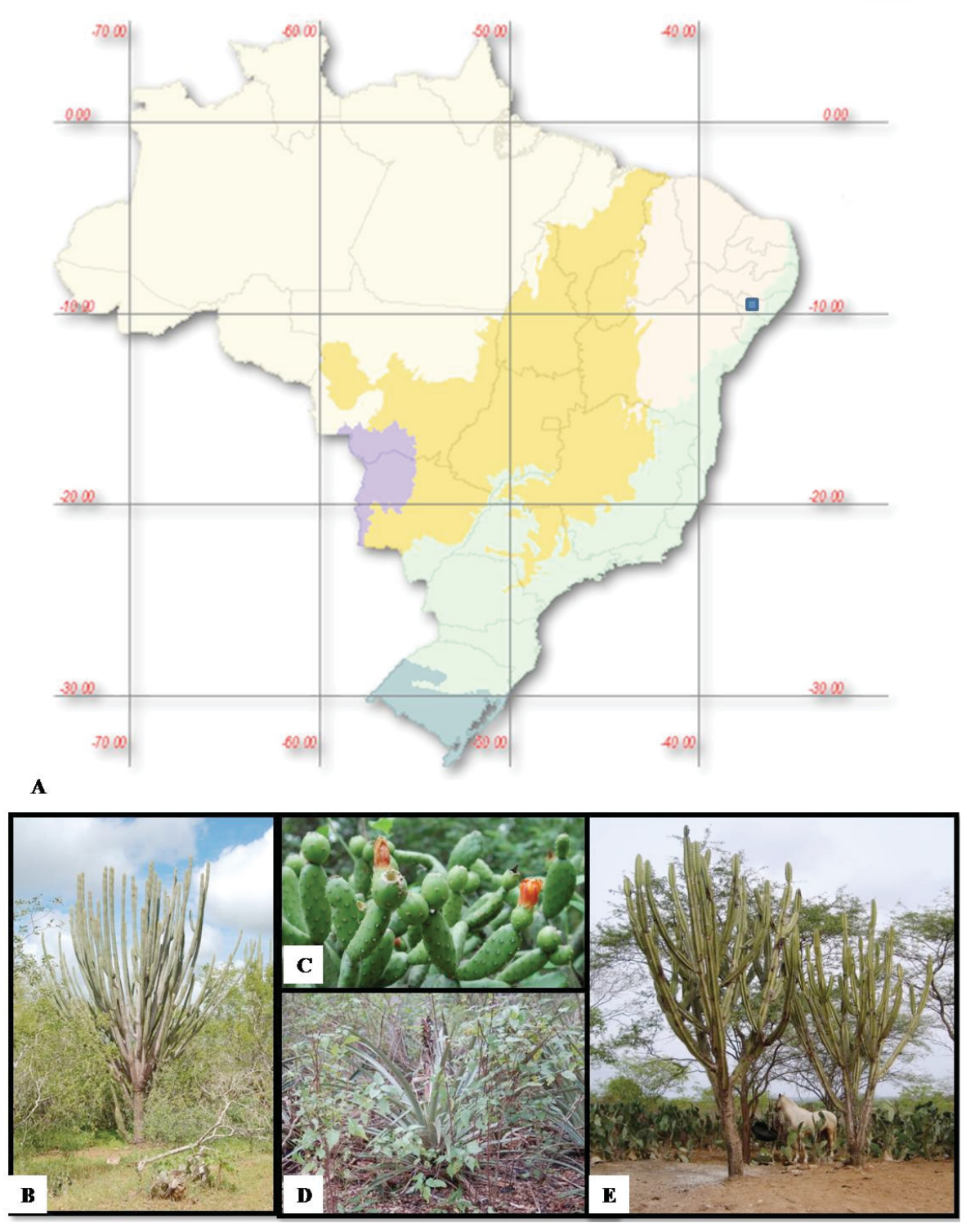

Paraíba, Pernambuco, Piauí, Rio Grande do Norte, Sergipe), southeastern (Minas Gerais, Rio de Janeiro, São Paulo) and southern (Paraná, Rio Grande do Sul, Santa Catarina) regions. Biomes: Amazonian, Caatinga, Cerrado and Atlantic rainforest (CAVALCANTI, 2013a).

Badhamia melanospora Speg., Anales Soc. Ci. Argent. 10:150 (1880). Figure 2.

Selected specimen. BRAZIL, Alagoas, municipality of São José da Tapera, on wood, 17 June, leg. A.C.C. Bezerra (UFP 80,046).
Recorded in Brazil in the northeastern (Ceará, Pernambuco, Rio Grande do Norte), and southern (Rio Grande do Sul) regions. This is the first report of this genus in Alagoas state. Biomes: Caatinga and Atlantic rainforest (CAVALCANTI, 2013a).

Cribraria violacea Rex, Proc. Acad. Nat. Sci. Philadelphia 43:393 (1891)

Selected specimen. BRAZIL, Alagoas, municipality of São José da Tapera, Opuntia sp., cultivated 19 June, sporulating 17 July, leg. A.C.C. Bezerra (URM 80,047). 
FIGURE 2: A - Badhamia melanospora Speg.; B - Physarum compressum Alb. \& Schwein; C - Didymium aff. dubium Rostaf.; D - Physarum pusillum (Berk. \& M.A.Curtis) G.Lister; E - Perichaena corticalis (Batsch) Rostaf.; F - Spores of Licea succulenticola Mosquera, Lado, Estrada \& Beltrán-Tej.

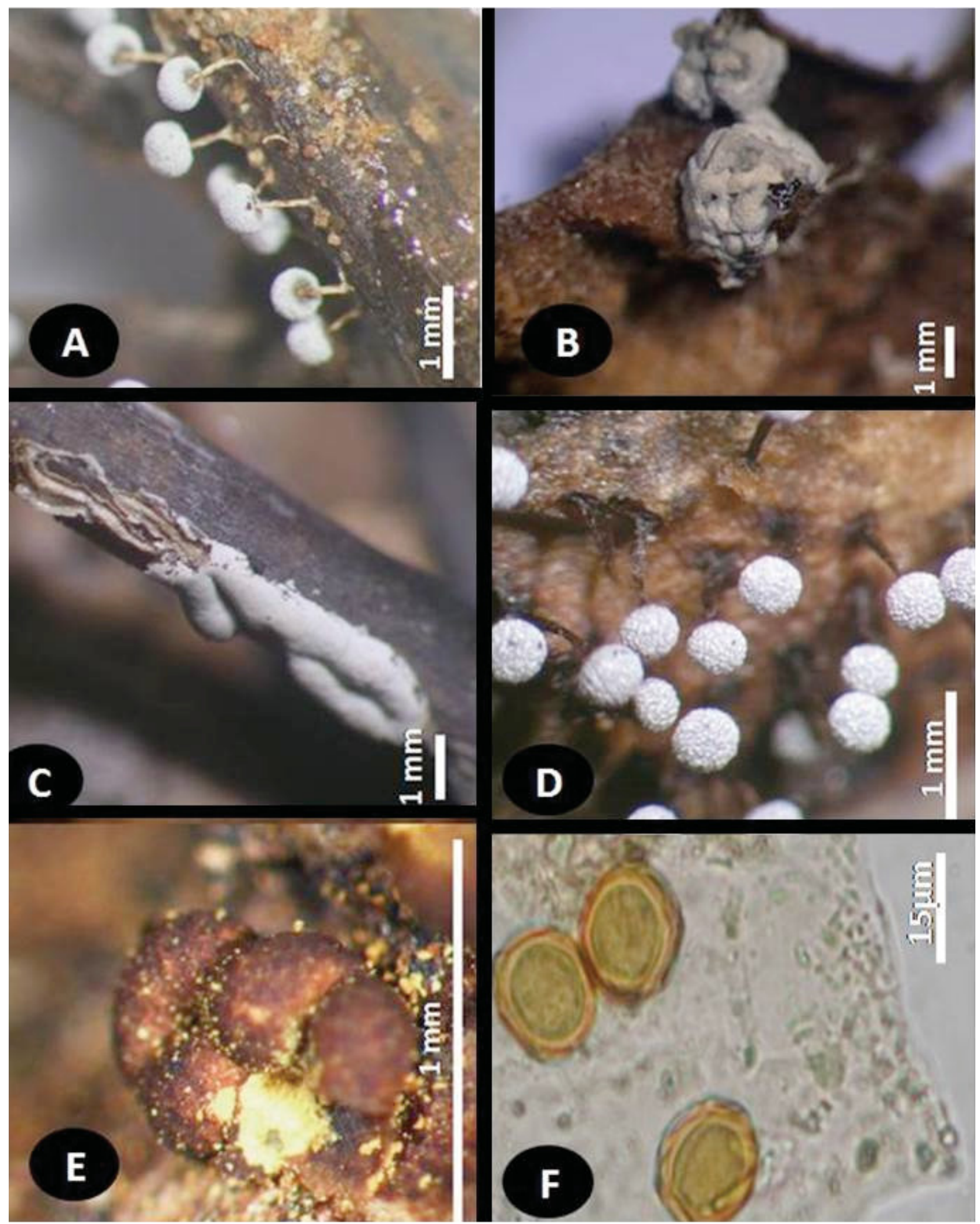


Recorded in Brazil in the northeastern (Alagoas, Bahia, Paraíba, Pernambuco, Piauí, Rio Grande do Norte, Sergipe), southeastern (São Paulo) and southern (Santa Catarina) regions. Biomes: Caatinga and Atlantic rainforest (CAVALCANTI, 2013a).

Comatricha laxa Rostaf., Sluzowce Monogr. 201 (1874)

Selected specimen. BRAZIL, Alagoas, municipality of São José da Tapera, Opuntia sp., cultivated 19 June, sporulating 17 July, leg. A.C.C. Bezerra (URM 80,039).

Recorded in Brazil in the northeastern (Pernambuco, Piauí, Sergipe), southeastern (São Paulo) and southern (Santa Catarina) regions and in the Atlantic rainforest biome (CAVALCANTI, 2013a). This is the first report of this genus in Alagoas state.

Didymium aff. dubium Rostaf., Sluzowce Monogr. 152 (1874). Figure 2

Selected specimens. BRAZIL, Alagoas, municipality of São José da Tapera, Opuntia sp., cultivated 19 June, sporulating 15 July, leg. A.C.C. Bezerra (UFP 54,898; 54,899). Ibdem, sporulating 25 July, leg. A.C.C. Bezerra (URM 80,040; 80,041). Ibdem, sporulating 04 Aug, leg. A.C.C. Bezerra (UFP 54,900; UFP 54,897). Ibdem, sporulating 11 Aug, leg. A.C.C. Bezerra (UFP 54,901).

Members of the family Didymiaceae are reported for the first time in Alagoas state. Biome: Cerrado (CAVALCANTI, 2013a).

Hemitrichia calyculata (Speg.) M.L. Farr, Mycologia 66(5):887 (1974)

Selected specimen. BRAZIL, Alagoas, municipality of São José da Tapera, on wood, 17 June, leg. A.C.C. Bezerra (UFP 54,894).

Recorded in Brazil in the northern (Acre, Amazonas, Pará, Roraima), northeastern (Alagoas, Bahia, Ceará, Paraíba, Pernambuco, Piauí, Rio Grande do Norte, Sergipe), southeast (Minas Gerais, Rio de Janeiro, São Paulo) and southern (Paraná, Rio Grande do Sul, Santa Catarina) regions and in the Amazonian, Caatinga, Cerrado and Atlantic rainforest biomes (CAVALCANTI, 2013a).

Licea succulenticola Mosquera, Lado, Estrada \& Beltrán-Tej., in Mosquera, Lado, Estrada-Torres,
Beltrán-Tejera \& Wrigley de Basanta, Anales Jard. Bot. Madrid 60(1):4 (2003)

Selected specimen. BRAZIL, Alagoas, municipality of São José da Tapera, Opuntia sp., cultivated 19 June, sporulation August 4, leg. A.C.C. Bezerra (URM 80,048). Recorded for the first time in Brazil.

Perichaena corticalis (Batsch) Rostaf., Sluzowce Monogr. 293 (1875). Figure 2

Selected specimen. BRAZIL, Alagoas, municipality of São José da Tapera, Opuntia sp., cultivated 19 June, sporulated 04 Aug, leg. A.C.C. Bezerra (UFP 54,900).

Recorded in Brazil in the northeastern region (Paraíba, Pernambuco), in the Caatinga, Cerrado and Atlantic rainforest biomes (CAVALCANTI, 2013a).

Physarum compressum Alb. \& Schwein., Consp. Fung. Lusat. 97 (1805)

Selected specimens. BRAZIL, Alagoas, municipality of São José da Tapera, Pilosocereus sp., cultivated 19 June, sporulated 25 June, leg. A.C.C. Bezerra (UFP 54,902; UFP 54,905). Ibdem, sporulated 29 June, leg. A.C.C. Bezerra (UFP 54,904). Ibdem, sporulated 04 Aug, leg. A.C.C. Bezerra (UFP 54,906). Ibdem, sporulated 09 Aug, leg. A.C.C. Bezerra (UFP 54,903). Ibdem, sporulated 09 Sept, leg. A.C.C. Bezerra (URM 80,049).

Recorded in Brazil in the northeastern (Alagoas, Bahia, Ceará, Maranhão, Pernambuco, Sergipe), southeastern (São Paulo) and southern (Paraná, Rio Grande do Sul, Santa Catarina) regions in the Caatinga and Atlantic rainforest biomes (CAVALCANTI, 2013a).

Physarum pusillum (Berk. \& M.A.Curtis) G.Lister, in Lister, Monogr. Mycetozoa, ed. 264 (1911) (Figure 2).

Selected specimen. BRAZIL, Alagoas, municipality of São José da Tapera, on wood, 17 June, leg. A.C.C. Bezerra (URM 80,046).

Recorded in Brazil in the northern (Acre, Amazonas, Pará, Roraima), northeastern (Bahia, Paraíba, Pernambuco, Piauí, Sergipe), midwestern (Goiás) and southeastern (São Paulo) regions. Although commonly found in Brazil, this is the first record of this species in 
Alagoas state. Biomes: Caatinga, Cerrado and Atlantic rainforest (CAVALCANTI, 2013a).

Reticularia jurana Meyl., Bull. Soc. Vaud. Sci. Nat. 44:297 (1908)

Selected specimen. BRAZIL, Alagoas, municipality of São José da Tapera, on wood, 17 June, leg. A.C.C. Bezerra (URM 80,044).

Recorded in Brazil in the northeastern (Alagoas, Paraíba, Pernambuco, Sergipe) and southeastern (São Paulo) regions in atlantic rainforest biome (CAVALCANTI, 2013a). This is the first report of this genus in Caatinga biome

Stemonaria longa (Peck) Nann.-Bremek., R.Sharma \& Y.Yamam., in Nannenga-Bremekamp, Yamamoto \& Sharma, Proc. Kon. Ned. Akad.Wetensch., C. 87(4):453 (1984)

Selected specimens. BRAZIL, Alagoas, municipality of São José da Tapera, on wood, cultivated 17 June, sporulated 04 Aug, leg. Bezerra A.C.C. (UFP 54,902; URM 80,045).

Recorded in Brazil in the northern (Amazonas, Roraima), northeastern (Bahia, Ceará, Paraíba, Pernambuco, Piauí), southeastern (Rio de Janeiro, São Paulo) and southern (Santa Catarina) regions. Biomes: Amazonian and Atlantic rainforest (CAVALCANTI, 2013a). This is the first report of this genus in Alagoas state, and in the Caatinga biome.

\section{Notes on species}

Didymium dubium has been reported from all of the continents except Africa. In the Neotropical region it has been cited in Argentina, Brazil, Colombia, Costa Rica, Dominican Republic, Ecuador, Guatemala, Mexico and Venezuela (LADO; WRIGLEY DE BASANTA, 2008; BEZERRA et al., 2008; LADO et al., 2013). This species is known as a nivicolous species, and is usually found between 2,000 and 4,000 $\mathrm{m}$ above sea level (FARR, 1976; LADO, 2004; LADO et al., 2005). The specimen recorded by Bezerra et al. (2008) sporulated on the leaves of Vellozia squamata Pohl. in a Cerrado area (210 $\mathrm{m}$ altitude), in the Serra de Itabaiana National
Park, Sergipe state (adjacent to Alagoas). Our specimen is differentiated from that found by Bezerra et al. (2008) by several features: the capillitium has dichotomously branched threads that do not form a network, the spores are more pale, and the ornamentation is more delicate, consisting of tiny warts. Lister (1925) commented that the spores of D. dubium can either be nearly smooth, or may have small spines. Martin and Alexopoulos (1969) and Farr (1976) reported a thickening at the base of the sporocarp resembling a columella; this characteristic has never been mentioned in any other Didymium species and was not observed in our study material.

Licea succulenticola is commonly found on specimens of Cactaceae [Austrocylindropuntia exaltata (A. Berger) Backeb, Copiapoa sp., Myrtillocactus geometrizans Console, Opuntia ficus-indica L., Opuntia streptacantha Lem., O. tomentosa Salm-Dyck and Stenocereus sp.], Euphorbiaceae (Euphorbia canariensis L.), Agavaceae (Agave sp., Agave americana L. A. atrovirens Karw., Aeonium sp., Yucca filifera Hort. ex Engelm.) and Ruscaceae (Nolina sp.) (MOSQUERA et al., 2003; LADO et al., 2007). The species is known to occur in Chile, Ecuador, Spain (Canary Islands), the United States and Mexico (MOSQUERA et al., 2003; MCHUGH, 2005; LADO et al., 2007).

Perichaena includes 31 species worldwide (LADO, 2013), but only five are known to occur in Brazil (CAVALCANTI, 2013b); this is the first record of this genus in Alagoas state. In the northeastern region, $P$. corticalis has been cited in the highlands of Paraíba state, and in urban gardens in Pernambuco state (CAVALCANTI, 2002). Cavalcanti (1974) mentioned that this species frequently occurs in Pernambuco, and undergoes a long period of sporulation - from March to September/October. Despite the numerous sporocarps usually found in this species, only one sporocarp was found in the specimen collected in Alagoas, which was co-occurring with D. dubium.

Reticularia Bull. is comprised of eleven species reported throughout the world (LADO, 2013), but only two, $R$. jurana Meyl. and $R$. lycoperdon Bull., have been reported in Brazil. In the northeastern region, this genus was recorded exclusively in Atlantic forest areas in Alagoas, Bahia, Paraíba, Pernambuco, Rio Grande 
do Norte and Sergipe states (CAVALCANTI, 2013c). The two analyzed specimens represent old sporangia collected from a decomposing tree trunk.

The genus Stemonaria Nann-Bremek., Sharma \& Y. Yamamoto was created in 1984 for Stemonitaceae species that did not fit into any genus, but which had several characteristics in common, including a hollow stipe (homogeneous or with longitudinal fibres) and the lack of a complete or partial peripheral capillitial network. The two species recorded in Brazil (Stemonaria longa and $S$. irregularis) were collected in different environments in Amazonas, Bahia, Ceará, Paraná, Pernambuco, Piauí, Rio de Janeiro, and São Paulo states (CAVALCANTI, 2013d).

Key to genera and species known to occur in Alagoas state. References: 1. Cavalcanti et al. (1985); 2. Santos et al. (1986); 3. Santos e Cavalcanti (1988); 4. Cavalcanti (2002); 5. Cavalcanti et al. (2006); 6. Cavalcanti (2013a; 2013b; 2013c; 2013d); 7. Results from this study.

1a. Sporophore sporocarpic or plasmodiocarpic. Endospore pigmented. .2

1b. Sporophore of branched columns. Exospore hyaline (Ceratiomyxa)

\section{C. fruticulosa (O.F. Müll.) T. Macbr. ${ }^{2,4,5}$}

2a. Sporangia or plasmodiocarps. 7

2b. Pseudoaetalia or aethalia ...3

3a. Sporophore an aethalium 4

3b.Sporophore a pseudoethalium. (Tubifera)

T. microsperma (Berk. \& M.A. Curtis) G.W. Martin ${ }^{5,6}$

4a. Lime absent. Capillitium absent, pseudocapillitium present. 5

4b. Lime present in the capillitium and on the peridium (Fuligo)

\section{F. septica (L.) F.H.Wigg. ${ }^{1,2,4,6}$}

5a. Aethalium pulvinated; peridium thin, membranous; pseudocapillitium membranous, made of perforated to thread-like plates.........(Reticularia) $R$. jurana Meyl. ${ }^{6,7}$

5b. Aethalium subglobose; peridium thick; pseudocapillitium of irregular, single or branched tubes .(Lycogala $) 6$

6a. Pseudocapillitium 10-25 $\mu \mathrm{m}$ diam.; spores 6,0-7,5 $\mu \mathrm{m}$ diam. L. epidendrum (L.) Fr. ${ }^{1,2,4,5}$

6b. Pseudocapillitium 2-10 u; spores (4) 4,5-5,5 (6) $\mu \mathrm{m}$ diam. L. exiguum Morgan ${ }^{5,6}$

7a. Bright-spored sporophores (whitish, yellowish, reddish, cinnamon to rust brown or with olive to greenish tint)

7b. Dark-spored sporophores (dark brown or purplish brow to black)........................................................... 8

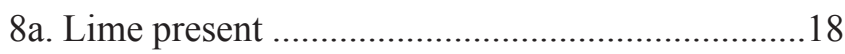

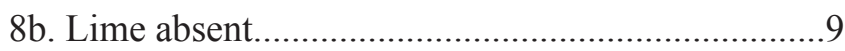

9a. Sporophore stalked; capillitium present..............11

9b. Sporophore sessile; capillitium absent .....(Licea) 10 10a. Spores thin-walled, pale yellow, globose to ovoid, minutely, densely, regularly verruculose, 9-12 $\mu \mathrm{m}$ diam. Licea biforis Morgan ${ }^{5,6}$

10b. Spores thick-walled, bright orange-yellow, subglobose to irregular, 11-14.5 x 12-16(17) $\mu \mathrm{m}$ diam., minutely and densely punctuate ................ Licea succulenticola Mosquera, Lado, Estrada \& Beltrán-Tej. ${ }^{7}$ 11a. Sporotheca cilindric. 13

11b. Sporotheca globose or sub-clindric. .12

12a. Peridium evanescent. Spores pale grey-brown or lilac-brown, verruculose ..... (Comatricha) C. laxa Rostaf. $^{7}$

12b. Peridium persisting as a collar after the upper portion has broken away. Spores violaceous grey, minutely punctate, sometimes with darker clusters (Collaria) C. arcyrionema (Rostaf.) Nann.-Bremek. ex Lado ${ }^{5,6}$ 13a. Capillitium with a complete or fragmented surface net. 14

13b. Capillitium without a surface net (Stemonaria) S. longa (Peck) Nann.-Bremek., R. Sharma \& Y.Yamam. 14a. Stalk and columella hollow, capillitum with a complete or nearly complete surface net.....(Stemonitis) 16 14b. Stalk and columella fibrous and solid at the base, 
hollow in the upper part. Capillitium with a fragmented surface net .(Stemonitopsis) 15

15a. Peridium often persistent, lilac-grey with a silvery shine. Spores 6-8 $\mu \mathrm{m}$ diam., cluster-warted...... S. typhina (F.H.Wigg.) Nann.-Bremek.,

15b. Peridium evanescent. Spores 10-11.5 $\mu \mathrm{m}$ diam., verruculose......S. subcaespitosa (Peck) Nann.-Bremek. ${ }^{3,4,6}$

16a. Spore asperulate. .17

16b. Spore spinulose-reticulate. ..S. fusca Roth $^{5,6}$

17a. Sporophore bright rusty brown; meshes capillitium mostly $<25 \mu \mathrm{m}$..... S. axifera (Bull.) T. Macbr. ${ }^{5,6}$

17b. Sporophore dark purplish brown to nearly black; meshes capillitium mostly $>25 \mu \mathrm{m}$ S. splendens Rostaf. $2,4,5,6$

18a. Lime present in the capillitium and on the peridium as rounded granules. 19

18b. Lime absent in the capillitium, present on the peridium as stellate crystals....(Didymium) $D$. aff. dubium Rostaf. ${ }^{7}$

19a. Sporophore a sessile sporocarp or a plasmodiocarp............................................... 31

19b. Sporophore a stalked sporocarp. 20

20a. Capillitium essentially homogeneous. 21

20b. Capillitium composed of two distinct, intermixed systems ......(Physarella) P. oblonga (Berk. \&M.A.Curtis) Morgan $^{5,6}$

21a. Capillitium consists of a net of thin, hyaline tubules; lime only present in nodes (Physarum).22

21b. Capillitium a net of lime-filled tubules; few or no limeless connecting tubules ....(Badhamia) $B$. melanospora Speg. ${ }^{7}$

22a. Sporotheca laterally compressed-globose or flat discoid.. .23

22b. Sporotheca globose .24

23a. Sporotheca fan-shaped, compressed-globose, compressed-reniform, varying to lobate. Spores purplish brown, warted, with warts sometimes irregularly distributed, 10-12.5 $\mu \mathrm{m}$ diam. .....P. compressum Alb. \&Schwein. ${ }^{5,6,7}$

23b. Sporotheca flat discoid to saucer-shaped. Spores pale violet brown, spinulose and with clusters of more prominent spines, $8-10 \mu \mathrm{m}$ diam....P. pezizoideum (Jungh.) Pavill. \&Lagarde ${ }^{5,6}$

24a. Lime present in the stalk . .25

24b. Lime absent in the stalk. .26

25a. Sporotheca yellow to dull orange. Columella small, conical ............. melleum (Berk. \& Broome) Massee ${ }^{5,6}$ $25 \mathrm{~b}$. Sporotheca grey to brownish grey. Columella absent. Pseudocolumella globose .......P. stellatum (Massee) G.W.Martin ${ }^{5,6}$

26a. True columella absent .27

$26 \mathrm{~b}$. True columella present, reaching about $80 \%$ of the height of the sporotheca ...................... penetrale $\operatorname{Rex}^{5,6}$

$27 \mathrm{a}$. Sporotheca white or gray. .28

$27 \mathrm{~b}$ Sporotheca yellow.. P. viride (Bull.)Pers. ${ }^{5,6}$

28a. Sporotheca globose.

28b. Sporotheca multilobate and compound-contorted. .P. nicaraguense T.Macbr. ${ }^{5,6}$

29a. Sporotheca gray .30

29b. Sporotheca gray, usually with a thickened red-brown base .............. pusillum (Berk. \&M.A.Curtis) G.Lister ${ }^{7}$

30a. Capillitium consisting of long, slender filaments originating at the sporangial base; lime nodes fusiform ..P. album (Bull.) Chevall. ${ }^{5,6}$

30b. Capillitium dense with small white, rounded lime nodes which are aggregated to form a ball in the center of the sporotheca ..P. nucleatum $\mathrm{Rex}^{5,6}$

31a. Peridium single. .32

31b. Peridium triple, yellow to brown; dehiscence lobate... P. bogoriense Racib. ${ }^{5,6}$

32a. Peridium thin, densely coated or flecked with lime... P. cinereum (Batsch) Pers ${ }^{5,6}$

32b Peridium usually densely covered with coarse, closely-set calcareous globules, rarely nearly limeless. P. vernum Sommerf. ${ }^{5,6}$ 
33a. Dictydine granules present; capillitium absent.....44

33b.Dictydine granules absent; capillitium present......34

34a. Columella present. Capillitial threads smooth..... 41

34b. Columella absent. Capillitial threads with ornamentation 35

35a. Capillitial threads without spiral bands ornamentation 38

35b. Capillitial threads with spiral bands ornamentation 36

36a. Sporangia stalked .37

36b. Reticulate plasmodiocarps..... (Hemitrichia) $H$. serpula (Scop.) Rostaf. Ex Lister ${ }^{5,6}$

37a. Peridium membranaceous, opening irregularly; Capillitum and spores yellow ...... H. calyculata (Speg.) M.L.Farr ${ }^{5,6,7}$

37b. Peridium cartilaginous, opening as a lid. Capillitium and spores orange red. (Metatrichia) ........vesparia (Batsch) Nann.-Bremek. Ex G.W. Martin \& Alexop. ${ }^{5,6}$

38a. Sporophore stalked, capillitium consisting of branched and anastomosing filaments ........(Arcyria) 39

38b. Sporophore sessile, capillitium consisting of simple filaments ..... (Perichaena) P. corticalis (Batsch) Rostaf. ${ }^{7}$

39a. Capillitium net free from the calyculus, attached to the tip of the stalk. A. magna $\operatorname{Rex}^{2,4,6}$

39b. Capillitium net attached to the calyculus 40

40a. Sporotheca deep red, fading to red-brown... .A. denudata (L.) Wettst. ${ }^{5,6}$

40b. Sporotheca pale grey ......A.cinerea (Bull.) Pers. ${ }^{2,3,4,5,6,7}$

41a. Sporocarps up to $150 \mu \mathrm{m}$....E. arboreum H.W.Keller $\&$ T.E.Brooks ${ }^{4,6}$

41 bSporocarps over $200 \mu \mathrm{m}$..... E. minutum de Bary ${ }^{4,6}$

42a. Peridium remaining as a system of longitudinal thickened bands .... C. cancellata (Batsch) Nann.Bremek. ${ }^{5,6}$

42b. Peridium remaining as a peridial net 43

43a. Sporotheca dark violet with a metallic shine C. violacea $\operatorname{Rex}^{5,6,7}$ 43b. Sporotheca yellow, orange-brown, yellow brown or dark brown ............................................ 44

44a. Threads of the peridial net sturdy, rounded, free or nearly free of dictydine granules, with rounded meshes on a line from base to apex .... C. confusa Nann.Bremek. \& Y.Yamam. ${ }^{5,6}$

44b. Peridial net connected by nodes with dictydine granules.

45a. Calyculus either absent or reduced to a small stellate collar C. microcarpa (Schrad.) Pers. ${ }^{5,6}$

45b. Calyculus usually present........................ 46

46a. Peridial net consisting of angular nodes with projections attached to the threads, usually with 5-8 threads connecting adjacent nodes C. intricata Schrad. ${ }^{5,6}$ 46b. Peridial net with small, regular meshes and prominent, small, round, dark nodes connected by 3-6 threads C. tenella Schrad. ${ }^{5,6}$

\section{Acknowledgements}

The authors acknowledge the National Council for Technological and Scientific Development (CNPq) for its financial support and productivity grant awarded to L. H. Cavalcanti (552615/05-6; 305967/2009-6; 301126/2005-4) and a post doc scholarship to A.C.C. Bezerra (PROTAX 150820/2008-9).

\section{References}

BEZERRA, M. F. A.; BEZERRA, A. C. C.; NUNES, A. T.; LADO, C.; CAVALCANTI, L. H. Mixobiota do Parque Nacional Serra de Itabaiana, Sergipe, Brasil: Physarales. Acta Botanica Brasilica, Feira de Santana, v. 22, n. 4, p. 1044-1056, 2008.

CAVALCANTI, L. H. O gênero Perichaena Fries em Pernambuco. Rickia, São Paulo, v. 6, p. 98-117, 1974.

CAVALCANTI, L H. Biodiversidade e distribuição de mixomicetos em ambientes naturais e antropogênicos no Brasil: espécies ocorrentes nas Regiões Norte e Nordeste. In: ARAÚJO, E. L.; MOURA, A. N.; SAMPAIO, E. V. S. B.; GESTINARI, L. M. S.; CARNEIRO, J. M. T. (Ed.). Biodiversidade, conservação e uso sustentável da flora do Brasil. Recife: Sociedade Botânica do Brasil, 2002. p. 209-216.

CAVALCANTI, L. H. Myxomycetes - Lista de espécies da flora do Brasil. Rio de Janeiro: Jardim Botânico, 2013a. Available in: $<$ http://floradobrasil.jbrj.gov.br/jabot/floradobrasil/FB95361>. Access: September 22, 2013. 
CAVALCANTI, L. H. Liceales - Lista de espécies da flora do Brasil. Rio de Janeiro: Jardim Botânico, 2013b. Available in: $<$ http://floradobrasil.jbrj.gov.br/jabot/floradobrasil/FB95295>. Access: September 22, 2013b.

CAVALCANTI, L. H. Trichiales - Lista de espécies da flora do Brasil. Rio de Janeiro: Jardim Botânico, 2013c. Available in: $<$ http://floradobrasil.jbrj.gov.br/jabot/floradobrasil/FB95361>. Access: September 22, 2013c.

CAVALCANTI, L. H. Stemonitales - Lista de espécies da flora do Brasil. Rio de Janeiro: Jardim Botânico, 2013d. Available in: $<$ http://floradobrasil.jbrj.gov.br/jabot/floradobrasil/FB95361>. Access: September 22, 2013.

CAVAlCANTI, L. H.; CORREIA, M. A. S.; PÔRTO, K. C. O herbário de myxomycetes (Gymnomycota) da UFPE. In: CONGRESSO NACIONAL DE BOTÂNICA, 35, 1982. Maceió. Resumos... Maceió: CNB, 1985. p. 189-200.

CAVALCANTI, L. H.; TAVARES, H. F. M.; NUNES, A. T. F.; SILVA, C. F. Mixomicetos, In: PÔRTO C. K. (Org.). Diversidade biológica e conservação da Floresta Atlântica ao Norte do Rio São Francisco. 1. ed. Brasília: Ministério do Meio Ambiente, 2006. p. 53-72.

CPRM - SERVIÇO GEOLÓGICO DO BRASIL. Diagnóstico do município de São José da Tapera, estado de Alagoas. In: MASCARENHAS, J. C. (Ed.). Projeto cadastro de fontes de abastecimento por água subterrânea. Recife: CPRM/ PRODEEM, 2005. p. 1-12.

FARR M. L. Flora Neotropica. Monograph 16. New York: New York Botanical Garden, USA, 1976. 304 p.

IRAWAN, B.; CLARK J.; STEPHENSON, S. L. Biosystematics of the Physarum compressum morpho species. Mycologia, Stanford, v. 92, p. 884-894, 2000.

LADO, C. Nivicolous myxomycetes of the Iberian Peninsula: considerations on species richness and ecological requirements", Systematics and Geography of Plants, Meise, v. 74, p. 143-157, 2004.

LADO, C. An on-line nomenclatural information system of Eumycetozoa. 2013. Available in: < http://www.nomen. eumycetozoa>. Access: September 25, 2013.

LADO, C.; BASANTA, D. W. A review of Neotropical Myxomycetes (1828-2008). Anales del Jardín Botánico de Madrid, Madrid, v. 65, n. 2, p. 211-254, 2008.

LADO, C.; PANDO, F. Myxomycetes. I. Ceratiomyxales, Echinosteliales, Liceales, Trichiales. Flora Mycologica Iberica, Consejo Superior de Investigaciones Cientificas (CSIC). Madrid: Real Jardín Botánico, 1997. 323 p.
LADO, C.; ESTRADA-TORRES, A.; STEPHENSON, S. L. Myxomycetes collected in the first phase of a north-south transect of Chile. Fungal Diversity, Chiang Mai, v. 25, n. 30, p. 81-101, 2007.

LADO, C.; RONIKIER, A.; RONIKIER, M.; DROZDOWICZ, A. Nivicolous Myxomycetes from the Sierra de Gredos (Central Spain). Nova Hedwigia, Stuttgart, v. 81, p. 371-394, 2005.

LISTER, A. A monograph of the Mycetozoa. London: British Museum Natural History, 1925. 222 p.

LADO, C.; BASANTA, D. W.; ESTRADA-TORRES, A.; STEPHENSON, S. L. The biodiversity of myxomycetes in central Chile. Fungal Diversity, v. 59, p. 3-32, 2013.

MARTIN, G. W.; ALEXOPOULOS, C. J. The Myxomycetes. Iowa City: University of Iowa Press, 1969. 560 p

MARTIN, G. W.; AleXOPOUlOS, C. J.; FARR, M. L. The genera of Myxomycetes. Iowa City: University of Iowa Press, $1983.560 \mathrm{p}$.

MCHUGH, R. Moist chamber culture and field collections of Myxomycetes from Ecuador. Mycotaxon, Ithaca, v. 92, p. 107-118, 2005.

MOSQUERA, J.; LADO, C.; ESTRADA-TORRES, A.; BELTRÁN TEJERA, E. Description and culture of a new Myxomycete, Licea succulenticola. Anales Jardín Botánico de Madrid, Madrid, v. 60, p. 3-10, 2003.

PEIXOTO, R. C.; LIMA JUNIOR, T. V. Impactos da evolução da dívida pública do estado de Alagoas. 2006. 77 f. Trabalho de Conclusão de Curso (Especialização em Gestão Pública) - Centro de Estudos Superiores de Maceió, Maceió. 2006.

PLGBB. Piranhas - folhas SC. 24-x-c- VI Sergipe/Alagoas/Bahia. Brasília: Programa de Levantamentos Geológicos Básicos do Brasil, 1988.

SANTOS, A. M. M.; TABARELLI, M. Distance from roads and cities as predictor of habitat loss and fragmentation in the Caatinga vegetation of Brazil, Revista Brasileira de Biologia, São Paulo, v. 62, n. 4B, p. 897-905, 2002.

SANTOS, E. J.; CAVALCANTI, L. H. Revisão de Myxomycetes ocorrentes en cana-de-açúcar (Saccharum spp.) en Brasil. Boletín Micológico, Valparaíso, v. 4, n. 1, p. 61-64, 1988.

SANTOS, E. J.; CAVALCANTI, L. H.; ALBUQUERQUE, W. C. Myxomycetes de Alagoas, In: CONGRESSO NACIONAL DE BOTÂNICA, 37, 1984, Ouro Preto, Resumos... Ouro Preto: CNB, 1986. p. 499-503.

STEPHENSON, S. L.; LANDOLF, J. C.; MOORE, D. L. Prostostelids, dictyostelids and Myxomycetes in the litter microhabitat of the Luquillo Experimental Forest, Puerto Rico, Mycological Research, Manchester, v. 103, p. 209-214, 1999. 